\title{
ODNOS UČITELJEV FRANCOŠČINE DO POUČEVANJA SLOVNICE
}

\section{UVOD}

Namen tega prispevka je predstaviti pomen in vlogo, ki jo učitelji francoščine na slovenskih srednjih šolah in gimnazijah pripisujejo slovnici pri svojem poučevanju. $V$ prispevku najprej opredelimo pojem slovnice ter orišemo njen položaj v različnih metodologijah, od slovnično-prevajalne metode do akcijsko usmerjenega poučevanja. Na odnos do slovnice in njene vloge pri učenju in poučevanju jezikov je precej vplival tudi dokument Skupni evropski jezikovni okvir: učenje, poučevanje, ocenjevanje (CECRL 2000; SEJO 2011).

Pomen slovnice pri pouku francoščine je opredeljen v dveh učnih načrtih, v Učnem načrtu za francoski jezik iz leta 1998 ter v Učnem načrtu iz leta 2008, ki je danes ključni dokument za učitelja pri načrtovanju in izvajanju pouka.

Spreminjanje vloge slovnice je predstavljeno skozi primerjavo dveh shem maturitetnega izpita na osnovni ravni (OR) za francoščino (iz leta 2007 in iz leta 2010), s shemo francoske diplome DELF, kjer se je pod vplivom sodobnih smernic poučevanja precej zmanjšal tudi delež slovnice.

V nadaljevanju prispevka je predstavitev zasnove raziskave in rezultatov empiričnega dela raziskovalne naloge. Želeli smo ugotoviti, kakšen pomen pripisujejo slovnici naši učitelji francoščine na srednjih šolah, zato smo v skladu s tem oblikovali raziskovalno vprašanje. Iz tega vprašanja smo izpeljali dve predpostavki, ki smo ju preverili v dveh med seboj smiselno povezanih pedagoških raziskavah: naredili smo analizo treh učbenikov ter izvedli spletni anketni vprašalnik, ki je vseboval štiri različne vsebinske sklope.

Ker je empirični del naloge precej obširen, $\mathrm{v}$ tem prispevku predstavljamo rezultate anketnih vprašalnikov, ki so relevantni za naše raziskovalno vprašanje.

\section{TEORETSKA IZHODIŠČA}

Slovnico je težko jasno in enoznačno opredeliti, saj se problem pojavi že pri opredelitvi izraza slovnica, ki je polisemičen. Podobna raznolikost se pojavi tudi pri poimenovanju 
različnih vrst slovnic. Poleg tega je bilo področje slovnice pri pouku jezikov z uveljavitvijo komunikacijskih pristopov precej zapostavljeno, kljub temu da je bilo področje tujejezikovnega učenja in poučevanja pogosto izpostavljeno različnim spremembam glede pristopov in metod.

Največ dilem v zvezi s poučevanjem slovnice se je pojavljalo na področju govornega sporočanja, precej več kot pri pisnem sporočanju (Germain in Séguin 1998: 35).

Slovnico, ki je osrednji predmet naše raziskave, smo zato poimenovali »šolska slovnica«, saj je povezana $\mathrm{z}$ učenjem in poučevanjem francoščine. $\mathrm{V}$ zvezi s poučevanjem slovnice se pojavljata dve ključni vprašanji in sicer vprašanje zaporedja (fr. progression) ter vprašanje izbire (fr. sélection) (Germain in Séguin 1998: 109) slovničnih struktur. Poleg tega si učitelji v zvezi s slovnico zastavljajo različna vprašanja o tem, kaj vpliva na slovnično progresijo pri pouku, o dodatnih metodah poučevanja za celostno razvijanje sporazumevalne zmožnosti, o izbiri ustreznih tipov nalog itd.

Vloga slovnice se je v različnih metodologijah, ki odsevajo različen odnos do poučevanja slovnice, močno spreminjala. Skela (2008: 185) navaja, da se je šele v 19. stoletju v večini evropskih dežel začelo res sistematično poučevanje tujih modernih jezikov.

Prav tako so se zaradi večjega razmaha poučevanja tujih jezikov začela porajati vprašanja glede izbire ustreznih metodologij za poučevanje.

Koncept slovnice danes razumemo predvsem kot pravila uporabe in rabe jezika ( $\mathrm{r}$. l'usage et l'emploi) v okviru nekega jezikovnega konteksta. S sodobnimi didaktičnimi smernicami postaja slovnica spet enakovreden element med ostalimi sestavinami sporazumevalne zmožnosti in tujejezikovni pouk že vsaj dve desetletji ni več sinonim za poučevanje slovnice (Germain in Séguin 1998: 41).

\subsection{Slovnica skozi zgodovino}

Slovnica je imela zelo pomembno vlogo v srednjem veku in v obdobju renesanse. Poučevala se je predvsem s tehnikami prevajanja, na ekspliciten način ter vključevala deduktivno učenje. V 18. stoletju je slovnično prevajalna metoda deloma prešla v intenzivno branje z analizo besedišča (Vučo 2012: 213). Svoj vrhunec je dosegla v 19. stoletju, ko so se z Gouinovo metodo in direktno metodo že začela pojavljati prva prizadevanja po drugačnih načinih poučevanja s poudarkom na govornem sporočanju.

Tradicionalna slovnično-prevajalna metoda je še danes kritizirana zaradi popolne odsotnosti sporazumevalne spretnosti. Vučo (2012: 236-237) tudi navaja, da je temelj induktivnemu učenju slovnice postavil Wilhelm Vietor.

Muster (2008: 384) pravi, da so že pri direktni metodi izhajali iz predpostavke, da naj bi se učenci jezika učili podobno kot materinščine in slovnico usvajali intuitivno oz. nezavedno.

Direktno metodo so zaradi številnih ovir nadomestile različne druge metode, ki so postopoma sooblikovale temelj današnjemu komunikacijskemu pristopu (Skela 2008: 179-180). 
Za avdio-lingvalno metodo, ki se je pojavila med drugo svetovno vojno in je temeljila na principih strukturalističnega jezikoslovja in behaviorizma, je bila značilna predstavitev slovničnih struktur v dialogih. Prisotna je bila torej implicitna slovnica, brez razlage.

V strukturo-globalni avdiovizualni metodologiji, ki se je pojavila po letu 1950 ( $f r$. Méthode structuro-globale audiovisuelle), je bila vloga slovnice predvsem v omogočanju razumevanja sporočilnosti jezika. V ospredju te metode so bili prozodični elementi, vendar brez slovničnih opisov in razlag (Boyer in drugi 1990: 203-204).

Posledično Skela (1999: 176-177) ugotavlja, da je komunikacijsko poučevanje jezikov skupek pristopov, ki so nastali v nasprotju s strukturalizmom in situacijskimi metodami v 60. letih in temeljijo na načelu, da sta pomembna tako tvorjenje slovnično pravilnih stavkov kot konkretna uporaba jezika pri izpeljavi nalog. V ospredju je sporazumevanje $\mathrm{v}$ tujem jeziku in ne teoretično znanje ter poznavanje metajezika.

Miquel (2007: 232) verjame, da se je torej komunikacijski pristop v zvezi s poučevanjem slovnice izkazal za bolj stimulativnega, saj je jezikovna vprašanja umeščal v konkreten, življenjski kontekst.

Zaključimo lahko torej z ugotovitvijo, da komunikacijski pristop ne zavrača učenja in poučevanja slovnice, celo vključuje jo in poudarja njeno pomembno vlogo pri učenju jezika, vendar na drugačen, bolj osmišljen način.

In nazadnje, akcijsko usmerjeni pristop je nadgradnja komunikacijskega pristopa, vendar z večjim poudarkom na opravilih ( $f r$. tâches), ki jih učenec oziroma dijak opravlja v ciljnem jeziku v različnih kontekstih ter v vsakdanjem življenju. Tudi v dokumentu SEJO (2011: 31) je zapisano, da je pri sporazumevanju in učenju tujega jezika potrebno izvajanje opravil, ki niso zgolj jezikovna.

\subsection{Slovnica v učnem načrtu za francoščino}

V učnem načrtu za francoščino za gimnazije (1998: 11) je slovnica opredeljena tako: »Za uspešno ustno in pisno komunikacijo $\mathrm{v}$ francoščini dijak [...] jezikovne strukture prepoznava, razume njihov pomen in jih zna uporabiti.«V zvezi z načinom poučevanja slovnice pa je eksplicitno zapisano, da učenje slovničnih struktur in besedišča ne more biti samo sebi namen. Pristop k poučevanju slovničnih struktur je kognitiven, še zlasti naj dijaki slovnične strukture usvajajo na induktiven način s primerjanjem, postavljanjem hipotez in lastnim odkrivanjem slovničnih pravil, pri tem pa jih usmerja učitelj z ustreznimi vajami, vprašanji in nalogami (prav tam; 40).

Avtorji posodobljenega učnega načrta, ki je izšel leta 2008, postavljajo v ospredje t. i. spiralni model učenja slovnice, kar pomeni, da se dijak k posameznim slovničnim vprašanjem večkrat vrača in jih smiselno nadgrajuje. Slovnica se poučuje predvsem induktivno, poučevanje pa naj temelji na opazovanju primerov.

»Induktivni način poučevanja slovnice dijakom predstavlja večji izziv, saj slovnična pravila z opazovanjem primerno izbranih primerov v čim večji meri odkrijejo sami. 
Vendar tak način poučevanja zahteva veliko časa, zato v razredu menjamo induktivni in deduktivni način poučevanja slovnice.« (UN 2008: 25-26). V dokumentu je tudi zapisano, da naj učitelj pri preverjanju in ocenjevanju znanja slovnice glede na cilj uporabi različne vaje, in če je le mogoče, preverja jezikovno znanje v kontekstu (prav tam; 37).

Skela (1999: 130) ugotavlja, da je induktivni pristop z izobraževalnega vidika iz številnih razlogov bolj zaželen, med drugim tudi zato, ker spominja na naravno usvajanje jezika in spodbuja učenčevo notranjo motivacijo itd.

\subsection{Spremenjena vloga slovnice pri maturi in francoski diplomi DELF in DALF}

V skladu s sodobnimi smernicami poučevanja tujih jezikov se je opazno spremenila prvotna vloga slovnice tudi na področju standardiziranega vrednotenja znanja. Slovnica je postala enakovreden del med drugimi elementi sporazumevalne zmožnosti. Komunikacijski pristop učenja in poučevanja jezikov je prešel $\mathrm{v}$ akcijski pristop poučevanja, $\mathrm{v}$ katerem slovnica nima več osrednje vloge, saj dijaki opazujejo jezik v neposredni rabi in v procesu rabe pridobivajo védenja o pojmih jezikovnega sistema (Cajhen 2013: 36).

Osnovni cilj maturitetnega izpita iz francoščine je, da dijaki pokažejo pričakovano raven sporazumevalne zmožnosti na višji in osnovni ravni zahtevnosti. Maturitetni izpit je zgrajen iz dveh delov. V pisnem delu so naloge za preverjanje različnih vsebin in spretnosti, katere del je tudi poznavanje in praktična raba slovničnih struktur in besedišča. Ustni del je namenjen izključno preverjanju govornega sporočanja in sporazumevanja. Slovnične strukture mora kandidat prepoznati in razumeti ter jih znati uporabiti v ustreznem kontekstu, ustno ali pisno. Nekatere slovnične strukture pa mora le prepoznati (PIK 2010: 21-34).

S posodobljenim Predmetnim izpitnim katalogom za splošno maturo pri francoščini, ki je bil v veljavi do leta 2012, se je zmanjšal delež ocene za jezikovni del, ki za razliko od prejšnjega kataloga (PIK SM 2007), znaša le 15 \% skupne ocene. Izpitna pola $1 \mathrm{~B}$ - Poznavanje in raba jezika je namreč v prejšnjem katalogu predstavljala kar $20 \%$ deleža ocene.

Predmetni izpitni katalog za splošno maturo Francoščina (2007) temelji na Učnem načrtu za francoščino iz leta 1998, Predmetni izpitni katalog za splošno maturo Francoščina iz leta 2010 pa izhaja iz smernic posodobljenega Učnega načrta za francoščino v gimnazijah iz leta 2008. Izhodišča za oba izpitna kataloga so poleg obeh učnih načrtov in sklepov Državne predmetne komisije za splošno maturo tudi učbeniška gradiva in priročniki, ki jih učitelji uporabljajo pri pouku in so bili potrjeni na Strokovnem svetu RS za splošno izobraževanje.

$\mathrm{V}$ nadaljevanju bomo predstavili primerjavo med shemo izpita na osnovni ravni (OR) za pisni del od leta 2009 dalje ter shemo izpita prav tako na osnovni ravni (OR) iz leta 2012, ki temelji na posodobljenem Učnem načrtu za francoščino v gimnazijah in na sklepih Državne komisije za maturo (Prikaz 1). 
Prikaz 1: Shema izpita (OR) - pisni del (2009) in shema izpita (OR) - pisni del (2012)

\begin{tabular}{|c|c|c|c|c|c|}
\hline $\begin{array}{l}\text { Izpitna } \\
\text { pola }\end{array}$ & Naslov & $\begin{array}{c}\text { Delež } \\
\text { pri oceni }\end{array}$ & $\begin{array}{l}\text { Izpitna } \\
\text { pola }\end{array}$ & Naslov & $\begin{array}{c}\text { Delež } \\
\text { pri oceni }\end{array}$ \\
\hline $1 \mathrm{~A}$ & Bralno razumevanje & $20 \%$ & $1 \mathrm{~A}$ & Bralno razumevanje & $20 \%$ \\
\hline $1 \mathrm{~B}$ & $\begin{array}{l}\text { Poznavanje in raba } \\
\text { jezika (različni jezikovni } \\
\text { problemi v kontekstu) }\end{array}$ & $20 \%$ & $1 \mathrm{~B}$ & $\begin{array}{l}\text { Poznavanje in raba } \\
\text { jezika (različni jezikovni } \\
\text { problemi v kontekstu) }\end{array}$ & $15 \%$ \\
\hline 2 & Slušno razumevanje & $10 \%$ & 2 & Slušno razumevanje & $15 \%$ \\
\hline 3 & Pisno sporočanje & & 3 & Pisno sporočanje & \\
\hline $3 \mathrm{~A}$ & $\begin{array}{l}\text { Krajši vodeni spis v eni od } \\
\text { stalnih oblik sporočanja }\end{array}$ & $10 \%$ & $3 \mathrm{~A}$ & $\begin{array}{l}\text { Krajši vodeni spis v eni od } \\
\text { stalnih oblik sporočanja }\end{array}$ & $10 \%$ \\
\hline \multirow[t]{2}{*}{3 B } & $\begin{array}{l}\text { Daljši pisni sestavek na } \\
\text { določeno temo }\end{array}$ & $20 \%$ & 3 B & $\begin{array}{l}\text { Daljši pisni sestavek na } \\
\text { določeno temo }\end{array}$ & $20 \%$ \\
\hline & SKUPAJ & $80 \%$ & & SKUPAJ & $80 \%$ \\
\hline
\end{tabular}

(PIK SM 2007: 9; PIK SM 2010: 8)

Primerjava obeh shem maturitetnih izpitov (Prikaz 1) kaže na to, da se je delež točk pri izpitni poli $1 \mathrm{~B}$, ki preverja poznavanje in rabo jezika, zmanjšal za $5 \%$ in iz tega lahko sklepamo, da se je pri maturitetnem izpitu iz francoščine v skladu s sodobnimi smernicami učenja in poučevanja francoščine zmanjšal obseg nalog, ki eksplicitno preverjajo znanje slovnice.

Vloga slovnice se je v zadnjih letih tudi pri obeh mednarodno veljavnih diplomah DELF in DALF opazno spremenila in danes ne obstaja več kot posebna kategorija znanja, ki bi jo ta diploma vključevala. Sporazumevalna zmožnost se vrednoti na vsaki ravni skozi štiri področja sporazumevanja: slušno razumevanje, govorno sporočanje, bralno razumevanje in pisno sporočanje, kjer pa je slovnična pravilnost nedvoumno vključena za vrednotenje obeh produktivnih zmožnosti.

$\mathrm{V}$ ospredju je vrednotenje različnih ravni sporazumevanja $\mathrm{v}$ francoščini, ne pa ločeno preverjanje znanja slovnice, besedišča in francoske kulture. Koncept izpitov je na vseh ravneh usklajen s sodobnimi pristopi in smernicami, zato so nekatere kategorije, ki so imele v preteklosti večji pomen in med katerimi je tudi slovnična zmožnost, odstopile svoje mesto drugim kategorijam (Miquel 2007: 30). Že pri sami obliki izpita DELF lahko opazimo večji poudarek na govornem sporočanju ter sporazumevanju in le manjši delež nalog, ki preverjajo jezikovno pravilnost, ustreznost besedišča, izgovorjavo in intonacijo (Prikaz 2). 
Prikaz 2: Shema izpita DELF

\begin{tabular}{|l|c|c|}
\cline { 2 - 3 } \multicolumn{1}{c|}{} & Trajanje & Ocena \\
\hline Slušno razumevanje (3-4 zvočni posnetki, 4 naloge) & 20 minut & $/ 25$ \\
\hline Bralno razumevanje (odgovori na vprašanja, 4-5 besedil) & 30 minut & $/ 25$ \\
\hline Pisno sporočanje (izpolnjevanje obrazcev, zapis kratkih povedi) & 30 minut & $/ 25$ \\
\hline Govorno sporočanje (voden pogovor, izmenjava informacij, simulacija) & $5-7$ minut & $/ 25$ \\
\hline
\end{tabular}

(Centre international d'études pédagogiques, april 2013)

\subsection{Izbira gradiv za poučevanje francoščine}

Pri pouku tujega jezika je poleg uporabe ustreznih metod in načinov poučevanja zelo pomembna izbira ustreznega konteksta, $v$ katerega se umesti poučevanje slovnice, tudi z upoštevanjem predznanja, zanimanja in posebnosti učencev ter dijakov. Različne metode poučevanja in njihova ustreznost se zagotovo najbolj jasno odslikavajo skozi različna gradiva, ki so jih v preteklosti oziroma jih danes učitelji uporabljajo pri svojem pouku.

Cuq in Gruca (2009: 281) ugotavljata, da objava učbenikov in drugih gradiv omogoča številne možnosti za metodološke raziskave, saj vsebuje vsak pedagoški material sledove iz preteklosti in hkrati spodbuja reakcije v sedanjosti.

Muster (2008: 384) je tudi prepričana, da mora učitelj izbrani učbenik pred uporabo najprej dobro proučiti ter ugotoviti povezavo med jezikovnim delom, govorom in vsebinskim branjem.

Vsekakor so tudi jezikovne naloge učinkovitejše takrat, kadar so vgrajene v ustrezen kontekst, pri čemer lahko učitelju, kot ugotavlja Lah (2008: 305-306), pomagajo tudi učbeniki, ki nudijo različne tipe vaj. Prav tako je prepričana, da imajo pri razumevanju in predstavljanju besedila pomembno vlogo tudi tipi besedil, ki so vključeni v gradiva.

Če je slovnica predstavljena na začetku vsake enote v učbeniku in dialog služi zgolj kot model slovničnih struktur, potem je ta učbenik izrazito nekomunikacijski. Značilnost nekomunikacijskih učbenikov je tudi, da vsebujejo vaje, usmerjene v posamezno slovnično strukturo, in mini dialoge, ki niso naravni (Courtillon 2003: 114-115) (gl. Primer 1).

\section{Primer 1: Zgled nenaravnega dialoga}

- $\quad$ Pierre arrive à la gare?
- Non, il arrive à l'aéroport.

(Courtillon 2003: 115)

Cuq in Gruca (2009: 276-277) sta kot sredstvo za sistematičen pregled in ustrezno izbiro učbenika uporabila preglednico, ki jo je oblikovala Bertoletti (Prikaz 3), v kateri vidimo, da slovnica nikakor ni izpuščena. 
Prikaz 3: Pet referenčnih področij učbenika
A. Predstavitev učbenika (naslovnica, dodatno gradivo, predgovor itd.)
B. Podporni dokumenti (besedila, slike, slušni posnetki)
C. Jezikovne vsebine (besedišče, fonetika, slovnica, vaje za fonetiko, morfo-sintaksa, semantika in izražanje)
D. Pomenska vsebina in tematika
E. Testi in evalvacija

(Cuq 2009: 276-277)

Slovnične vaje, ki so v sodobnih učbenikih za učenje francoščine, niso namenjene izključno učenju slovnice, temveč lahko z osmišljeno rabo pri pouku tudi spodbujajo razumevanje jezikovnega sistema, vključno z maternim jezikom in omogočajo konceptualizacijo, razvrščanje jezikovnih znanj, pomnjenje ter hranjenje jezikovnih oblik (Girardet 1988: 6).

Treba se je zavedati, da je učbenik zgolj gradivo za poučevanje jezika in da mora pouk potekati v skladu s sodobnimi smernicami, ki so zapisane v učnem načrtu.

\section{EMPIRIČNI DEL}

\subsection{Uvod v empirični del}

Omenili smo že, da je slovnico težko enoznačno opredeliti, zato smo v naši raziskavi izhajali iz opredelitve sporazumevalne zmožnosti po SEJO (2011: 132). Prav tako smo se oprli na tradicionalno opredelitev slovnične zmožnosti, ki slovnico deli na oblikoslovje in skladnjo. Naša raziskava pa je bila usmerjena v t.i. šolsko slovnico. Najprej smo oblikovali raziskovalno vprašanje o pomenu, ki ga pripisujejo učitelji francoščine slovnici na slovenskih gimnazijah in srednjih šolah. Oblikovali smo dve predpostavki, ki smo ju skozi raziskavo preverili in sicer:

\section{Predpostavka 1: Slovenski učitelji francoščine pripisujejo slovnici velik pomen pri svojem pouku.}

To predpostavko smo najprej preverjali z analizo treh najbolj uporabljenih učbenikov po časovni osi za obdobje dvajsetih let in nato še v osrednji raziskavi z analizo vprašalnikov, v katerih sta bili dve poglavji usmerjeni izključno v učna gradiva ter v slovnico pri pouku francoščine.

\section{Predpostavka 2: Učitelji, ki pripisujejo slovnici večji pomen, uporabljajo učbenike, kjer je več slovničnih vaj.}

Tudi predpostavko 2 smo preverjali z analizo treh učbenikov in anketnih vprašalnikov. Prav tako smo ugotavljali povezave med obema raziskavama, med dobljenimi rezultati analize učbenikov in odgovori anketirancev. 


\subsection{Metodologija}

Uporabili smo dve metodi pedagoškega raziskovanja: a) analizo gradiv, s katero smo želeli preveriti delež jezikovnih vaj v treh najpogosteje uporabljenih učbenikih za obdobje preteklih dvajsetih let in b) kvantitativno metodo anketiranja. Ker se analiza gradiv redko uporablja kot samostojna tehnika raziskovanja, smo jo nadgradili še z osrednjo raziskavo, ki smo jo izpeljali z uporabo vprašalnika in jo bomo predstavili $\mathrm{v}$ nadaljevanju našega prispevka.

Za pridobitev kvantitativnih podatkov o pomenu slovnice za srednješolske učitelje francoščine smo uporabili anketni vprašalnik. Cilj te raziskave je bil preveriti in določiti vlogo slovnice ter pomen teoretičnih jezikovnih znanj pri pouku francoščine v slovenskih srednjih šolah s perspektive učiteljev. Poleg tega smo skušali ugotoviti, katerim didaktičnim smernicam sledijo naši učitelji pri svojem pouku, ali je delež slovnice v učnih gradivih, ki jih uporabljajo, ustrezen, katere tipe vaj uporabljajo za preverjanje slovnice, kateri način poučevanja slovnice (induktiven, deduktiven) se jim zdi bolj primeren.

Vprašalnik je bil anketirancem na voljo v papirnati in spletni obliki. Spletni vprašalnik smo oblikovali v spletni aplikaciji $1 \mathrm{ka}$. Vprašanja so bila $\mathrm{v}$ obeh vprašalnikih identična in so bila večinoma zaprtega tipa, razen treh zaključnih vprašanj v zadnjem sklopu. Vprašalnik je bil razdeljen na štiri različne vsebinske sklope:

- vprašanja o osnovnih podatkih učiteljev francoščine,

- vprašanja o poučevanju francoščine,

- vprašanja o učbeniških gradivih pri pouku francoščine,

- vprašanja o slovnici in njenem pomenu.

\subsection{Opis vzorca}

Na anketni vprašalnik se je odzvalo 40 učiteljev francoščine, in glede na podatke (Zavod RS za šolstvo), ki govorijo o tem, da je na srednji šoli oziroma gimnaziji v povprečju en učitelj, ki poučuje francoščino kot drugi ali tretji tuji jezik, bi lahko sklepali, da smo dobili odgovore od učiteljev francoščine s 40 različnih slovenskih gimnazij in srednjih šol.

Na osnovi seznama vseh srednjih šol s poukom francoščine, ki smo ga prejeli s strani Ministrstva za izobraževanje znanost in šport, smo iz celotne populacije vseh slovenskih učiteljev francoščine $(\mathrm{N}=46)$ prejeli odgovore od 40 učiteljev in na podlagi tega lahko sklepamo, da se je na naš vprašalnik odzvalo $87 \%$ učiteljev.

Kljub temu pa moramo biti pri posploševanju rezultatov anketnega vprašalnika previdni, saj je možno, da je na vprašalnik odgovoril tudi kakšen učitelj, ki v šolskem letu 2012/2013 ni poučeval francoščine ali sploh nobenega predmeta. 


\subsection{Rezultati in interpretacija}

Zaradi obsežnosti raziskovalne naloge predstavljamo v tem prispevku samo osrednji del raziskave $\mathrm{z}$ vprašalniki, ki vsebuje rezultate povezane $\mathrm{z}$ obema izbranima, zgoraj navedenima predpostavkama.

Prve predpostavke, ki predvideva, da slovenski učitelji francoščine pripisujejo slovnici velik pomen pri svojem pouku, ne moremo popolnoma potrditi, saj so povprečja pri posameznih spremenljivkah glede vloge slovnice nekoliko nižja, kot smo pričakovali. Vendar pa lahko na osnovi vrednosti posameznih spremenljivk, ki so nad povprečjem, zaključimo z ugotovitvijo, da se anketiranim učiteljem francoščine slovnica zdi pomembna in po njihovem mnenju predstavlja enakovreden element med vsemi drugimi sestavnimi elementi sporazumevalne zmožnosti.

Iz rezultatov je tudi razvidno, da so njihova mnenja o pomenu slovnice nekoliko manj enotna, kadar so poleg slovnice navedene še druge komponente tujejezikovnega pouka. Večja dilema se pri učiteljih pojavi tudi takrat, ko se vprašanje navezuje na izbiro ustreznih in učinkovitih didaktičnih pristopov $\mathrm{k}$ poučevanju slovnice.

$\mathrm{V}$ nadaljevanju predstavljamo rezultat vprašanja, pri katerem so anketirani učitelji označili, kako pogosto poleg drugih petih pristopov vključujejo v svoje poučevanje slovnični pristop (Prikaz 4).

Prikaz 4: Slovnični pristop pri poučevanju

\begin{tabular}{|l|c|c|c|c|c|}
\hline Q 7 Način poučevanja & N & Min. & Maks. & Povprečje & St. odklon \\
\hline $\begin{array}{l}\text { Q 7 a Razvijanje sporazumevalnih spretnosti } \\
\text { (slušno, bralno, govorno, pisno) }\end{array}$ & 40 & 3 & 5 & 4,3 & 0,65 \\
\hline Q 7 b Na nalogah temelječ pristop & 40 & 2 & 5 & 4,0 & 0,85 \\
\hline Q 7 f Slovnični pristop & $\mathbf{4 0}$ & $\mathbf{2}$ & $\mathbf{5}$ & $\mathbf{3 , 4}$ & $\mathbf{0 , 7 4}$ \\
\hline Q 7 d Poučevanje s pomočjo tehnologije - IKT & 40 & 2 & 5 & 3,3 & 0,72 \\
\hline $\begin{array}{l}\text { Q 7 e Poučevanje nejezikovnih vsebin } \\
\text { v francoščini (recimo medpredmetno } \\
\text { povezovanje) }\end{array}$ & 40 & 1 & 4 & 2,7 & 0,79 \\
\hline Q 7 c Projektni pristop & 40 & 1 & 4 & 2,6 & 0,71 \\
\hline
\end{tabular}

Rezultat njihovih odgovorov o pogostosti vključevanja slovničnega pristopa $\mathrm{v}$ pouk kaže na to, da učitelji večkrat ali pogosto vključujejo ta pristop, vendar je po pomembnosti šele na tretjem mestu in malo nad povprečjem uporabe vseh ostalih šestih predlaganih pristopov. Standardni odklon je pri slovničnem pristopu večji $(0,74)$ kot pri drugih pristopih, kar kaže na manjšo usklajenost med mnenji anketiranih učiteljev.

Pri naslednjem vprašanju Q 9 so učitelji označili, koliko se strinjajo s trditvami, ki se nanašajo na didaktične smernice pri poučevanju francoščine (Prikaz 5). 
Prikaz 5: Poudarek na jezikovni zmožnosti in pravilnosti

\begin{tabular}{|l|c|c|c|c|c|}
\hline Q 9 & N & Min. & Maks. & Povprečje & St. odklon \\
\hline $\begin{array}{l}\text { Q 9 f Pri poučevanju se omejim na določeni } \\
\text { specifični področji sporazumevalne zmožnosti: } \\
\text { jezikovno zmožnost in jezikovno pravilnost. }\end{array}$ & 40 & 1 & 4 & 3,0 & 0,90 \\
\hline
\end{tabular}

Učitelji se s trditvijo, da se pri poučevanju omejujejo na določeni specifični področji sporazumevalne zmožnosti, niti ne strinjajo niti je ne zavračajo, zato imata ti dve specifični področji povprečno vrednost 3,0. Tudi pri tej spremenljivki je standardni odklon višji $(0,90)$ kot pri drugih spremenljivkah, kar pomeni, da so mnenja učiteljev glede vključevanja izključno jezikovne zmožnosti in jezikovne pravilnosti $\mathrm{v}$ pouk zelo deljena.

V nadaljevanju sledi prikaz o tem, kako so anketirani učitelji označili vlogo slovnice pri pouku francoščine (Prikaz 6 ).

Prikaz 6: Pomembnost slovnične zmožnosti pri pouku

\begin{tabular}{|l|c|c|c|c|c|}
\hline Q 10 Trditev & N & Min. & Maks. & Povprečje & St. odklon \\
\hline Q 10 b - Leksikalna zmožnost (besedišče) & 40 & 4 & 5 & 4,6 & 0,50 \\
\hline Q 10 d - Fonološka zmožnost & 40 & 3 & 5 & 4,4 & 0,63 \\
\hline Q 10 f - Učne strategije (učenje učenja) & 40 & 2 & 5 & 4,3 & 0,76 \\
\hline Q 10 e - Medkulturna ozaveščenost & 40 & 2 & 5 & 4,3 & 0,72 \\
\hline Q 10 a - Slovnična zmožnost (slovnica) & 40 & 3 & 5 & 4,1 & 0,59 \\
\hline Q 10 c - Pravopisna zmožnost & 40 & 3 & 5 & 3,9 & 0,57 \\
\hline
\end{tabular}

Kljub temu, da se slovnična zmožnost glede na povprečne vrednosti po mnenju anketirancev umešča po pomembnosti šele na peto mesto, ima precej visoko povprečno vrednost $(4,1)$, iz česar lahko sklepamo, da se učiteljem zdi slovnična zmožnost pomembna. Poudariti je treba, da so njihova mnenja precej bolj usklajena (standardni odklon 0,59) kot pri spremenljivki Q 7, ki se je nanašala na slovnični pristop.

Učiteljem se zdi slovnična zmožnost za znanje tujega jezika pomembna, kljub temu pa se pri svojem poučevanju v povprečju redko omejijo izključno na jezikovno zmožnost in jezikovno pravilnost, kar smo lahko opazili že v prej predstavljenih rezultatih za spremenljivki Q $7 \mathrm{f}$ (Slovnični pristop) in Q $9 \mathrm{f}$ (Omejitev na dve področji sporazumevalne zmožnosti).

Še več, iz odgovorov anketiranih učiteljev je mogoče sklepati, da največ učiteljev (37,5 \%) označuje slovnico kot pomembno, 30 \% jo označuje kot zelo pomembno in 25 $\%$ kot manj pomembno. V nadaljevanju sledi še grafični prikaz ( $\underline{\text { Prikaz } 7)}$. 
Prikaz 7: Prikaz pomena slounice za učitelje francoščine

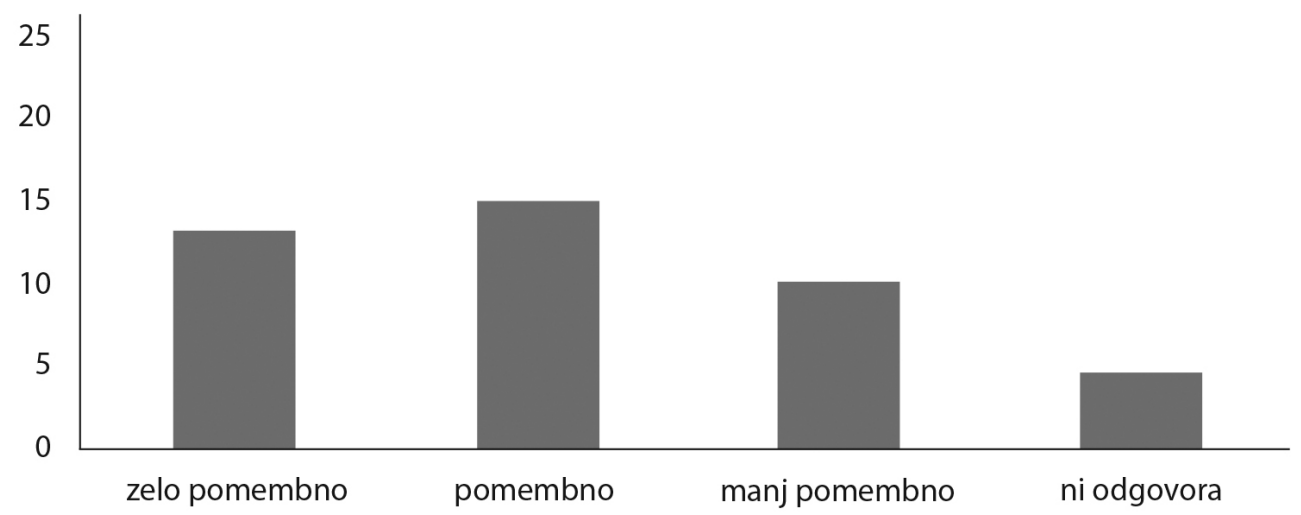

Zadnji sklop vprašanj v vprašalniku so bila odprta vprašanja o poučevanju slovnice, o posebnostih ter pomenu znanja slovnice. Iz odgovorov učiteljev lahko sklepamo, da se dijakom zdi slovnica manj pomembna kot učiteljem. Rajši imajo deduktivno poučevanje slovnice, saj je po njihovem mnenju tak način učenja jezika manj zahteven.

Učiteljem pa se zdi učenje francoske slovnice pomembno, saj je po njihovem mnenju eno izmed osnovnih orodij za sporazumevanje. So tudi mnenja, da mora potekati učenje slovnice v kontekstu in osmišljeno ter z veliko dodatnih vaj, zato dijake pogosto spodbujajo k samostojnemu razmišljanju in odkrivanju jezikovnih zakonitosti.

Iz njihovih odgovorov je tudi razvidno, da učitelji uporabljajo induktivno metodo poučevanja ob prvem opazovanju in tvorbi jezikovnih oblik, deduktivno pa predvsem za sistematičen prikaz le-teh. To pomeni, da naši učitelji kombinirano uporabljajo oba načina poučevanja, deduktivnega in induktivnega.

Druga predpostavka v tej raziskavi predvideva, da tisti učitelji, ki pripisujejo slovnici večji pomen, uporabljajo učbenike, kjer je več slovničnih vaj.

V nadaljevanju članka sledijo rezultati raziskave, na osnovi katerih lahko v celoti potrdimo to predpostavko. Že v prvem delu raziskave, kjer smo analizirali tri najpogosteje rabljene učbenike za obdobje dvajsetih let, smo ugotovili, da se je delež slovničnih vaj v zadnjem sodobnem učbeniku Scénario 1 zmanjšal skoraj za polovico. V tem učbeniku je poudarjena induktivna metoda učenja slovnice in skoraj ena četrtina vaj od vseh slovničnih vaj je zasnovanih tako, da spodbujajo dijake k opazovanju in razmišljanju o delovanju jezikovnega sistema. Sodobni učbeniki, kot sta Scénario 1 in Panorama 1, so tudi bolj komunikacijski in nekoliko manj sistematični.

Izvedli smo korelacijo med štirimi spremenljivkami (Q 11 i, Q 11 k, Q 12 b in Q 12 c), na osnovi katere smo želeli ugotoviti, ali se tistim anketiranim učiteljem, ki pri pouku uporabljajo komunikacijsko usmerjena učbenika Panorama 1 in Scénario 1, zdi razlaga slovničnih pravil in količina slovničnih vaj v obeh učbenikih, ustrezna in zadostna (Prikaz 8). 
Prikaz 8: Ustreznost razlage in količina jezikovnih poglavij

\begin{tabular}{|c|c|c|c|c|c|c|}
\hline & Učbenik & $\mathbf{N}$ & Povpr. & $\begin{array}{c}\text { St. } \\
\text { odklon }\end{array}$ & Min. & Maks. \\
\hline \multirow{2}{*}{$\begin{array}{l}\text { Q } 12 \text { b Jezikovna } \\
\text { poglavja so v } \\
\text { učbeniku ustrezno } \\
\text { razložena. }\end{array}$} & $\begin{array}{l}\text { Q } 11 \text { i: Panorama } 1 \\
\text { (leto potrditve: } 2008 \text { ) }\end{array}$ & 5 & 3,0 & 1,00 & $\begin{array}{l}2-\mathrm{Ne} \\
\text { strinjam se. }\end{array}$ & $\begin{array}{l}4-\text { Strinjam } \\
\text { se. }\end{array}$ \\
\hline & $\begin{array}{l}\text { Q } 11 \text { k: Scénario } 1 \\
\text { (leto potrditve: 2009) }\end{array}$ & 9 & 3,1 & 0,93 & $\begin{array}{l}2-\mathrm{Ne} \\
\text { strinjam se. }\end{array}$ & $\begin{array}{l}\text { 4-Strinjam } \\
\text { se. }\end{array}$ \\
\hline \multirow{2}{*}{$\begin{array}{l}\text { Q } 12 \text { c V učbeniku } \\
\text { je dovolj nalog, ki } \\
\text { razvijajo jezikovna } \\
\text { znanja (naloge, ki } \\
\text { izrecno preverjajo } \\
\text { slovnična znanja). }\end{array}$} & $\begin{array}{l}\text { Q } 11 \text { i: Panorama } 1 \\
\text { (leto potrditve: 2008) }\end{array}$ & 5 & 2,2 & 0,45 & $\begin{array}{l}2-\mathrm{Ne} \\
\text { strinjam se. }\end{array}$ & $\begin{array}{l}3 \text { - Niti se ne } \\
\text { strinjam niti } \\
\text { se strinjam. }\end{array}$ \\
\hline & $\begin{array}{l}\text { Q } 11 \text { k: Scénario } 1 \\
\text { (leto potrditve: 2009) }\end{array}$ & 9 & 2,7 & 0,87 & $\begin{array}{l}2-\mathrm{Ne} \\
\text { strinjam se. }\end{array}$ & $\begin{array}{l}4 \text {-Strinjam } \\
\text { se. }\end{array}$ \\
\hline
\end{tabular}

$\mathrm{Na}$ osnovi rezultatov v preglednici je mogoče sklepati, da tisti anketirani učitelji, ki uporabljajo učbenika Panorama 1 in Scénario 1, niso opredeljeni glede ustreznosti razlage jezikovnih poglavij, morda se k ustreznosti glede slovnice nekoliko bolj nagibajo uporabniki učbenika Scénario 1 (Prikaz 8). Ker pa je st. odklon visok, to pomeni, da njihova mnenja o ustreznosti razlage jezikovnih poglavij v obeh učbenikih, Panorama 1 in Scénario 1 niso usklajena. Menijo tudi, da je v obeh učbenikih premalo vaj in nalog, ki bi bile namenjene poglobljenemu razvijanju jezikovnih znanj. V učbeniku Scénario 1 je delež jezikovnih vaj po njihovem mnenju večji kot v Panorama 1, vendar še vedno pod povprečjem pričakovanj anketiranih učiteljev.

Učitelji francoščine niso opredeljeni glede ustreznosti razlage v sodobnih učbenikih, kjer prevladuje induktivni način poučevanja slovnice. Kot smo že zgoraj omenili, se sami namreč nagibajo bolj h kombinirani metodi poučevanja, večina anketiranih učiteljev uporablja pri slovnici kombinacijo obeh načinov poučevanja slovnice, deduktivni in induktivni način. Skupno pa jim je mnenje, da v nobenem od obeh sodobnih učbenikov ni dovolj slovničnih nalog.

Učbenik se jim sicer zdi pomembno gradivo, vendar le ta zaradi premajhnega števila slovničnih vaj in nekoliko tudi zaradi manj ustrezne razlage, po njihovem mnenju ne zadošča za razlago slovnice in urjenje slovničnih oblik, zato za razlago in urjenje jezikovnih oblik dodajajo še druga gradiva (Prikaz 9), kar počne večina učiteljev.

V nadaljevanju sledi prikaz treh spremenljivk, katerih vrednosti pomenijo, da učitelji v večini pri razlagi slovnice uporabljajo poleg učbenika še druga dodatna učna gradiva.

Prikaz 9: Mnenje o gradivih za poučevanje francoščine

\begin{tabular}{|l|c|c|c|c|c|}
\hline Q 12 Trditev & N & Min. & Maks. & Povprečje & St. odklon \\
\hline $\begin{array}{l}\text { Q } 12 \text { g Za razlago slovnice uporabljam še druga } \\
\text { gradiva. }\end{array}$ & 40 & 4 & 5 & 4,6 & 0,50 \\
\hline $\begin{array}{l}\text { Q } 12 \text { a Učbenik se mi zdi pomembno učno gradivo } \\
\text { za delo v razredu. }\end{array}$ & 40 & 3 & 5 & 4,2 & 0,66 \\
\hline $\begin{array}{l}\text { Q } 12 \text { b Jezikovna poglavja so v učbeniku, ki ga } \\
\text { uporabljam, ustrezno razložena. }\end{array}$ & 40 & 1 & 4 & 3,0 & 0,89 \\
\hline
\end{tabular}


Menijo tudi, da nekatera jezikovna poglavja v učbenikih, ki jih uporabljajo, niso dovolj razložena, v učbenikih tudi ni dovolj slovničnih vaj in da tudi pripadajoči delovni zvezek ne zadošča za uspešno ponotranjenje jezikovnih pravil. Tudi iz tega lahko sklepamo, da se učiteljem zdi slovnica pomembna in da v povprečju največ učiteljev uporablja dodatna gradiva za razlago jezikovnih pravil in tudi standardni odklon, ki je tu najnižji, kaže na precejšno usklajenost njihovih mnenj.

V zadnjem sklopu vprašalnika, ki je vseboval tri odprta vprašanja in se je navezoval izključno na poučevanje slovnice, je bilo vprašanje o tipih vaj in nalog, ki jih učitelji pri pouku najpogosteje uporabljajo za urjenje jezikovnih struktur (Prikaz 10). Anketirani učitelji so med trinajstimi predlaganimi tipi nalog označili pet, ki pri njihovem pouku prevladujejo.

Prikaz10: Tipi vaj za preverjanje znanja slovnice

\begin{tabular}{|l|c|c|}
\hline $\begin{array}{l}\text { Q } 13 \text { Katere tipe nalog uporabljate za preverjanje znanja slovnice? } \\
\text { Označite } \mathbf{5} \text { najpogostejših tipov nalog, ki pri vašem pouku } \\
\text { prevladujejo. }\end{array}$ & Pogostost & Delež \\
\hline Naloge vstavljanja & 31 & $77,5 \%$ \\
\hline Nadomeščanje kategorij (recimo sedanjik/preteklik, ednina/množina) & 25 & $62,5 \%$ \\
\hline Tvorjenje stavkov po danem vzorcu & 24 & $60,0 \%$ \\
\hline Naloge dopolnjevanja & 23 & $57,5 \%$ \\
\hline Kratki odgovori & 18 & $45,0 \%$ \\
\hline Naloge povezovanja & 16 & $40,0 \%$ \\
\hline Povezovanje in združevanje povedi (recimo nominalizacija) & 16 & $40,0 \%$ \\
\hline Naloge za urjenje oblik & 15 & $37,5 \%$ \\
\hline Naloge izbirnega tipa & 13 & $32,5 \%$ \\
\hline Naloge alternativne izbire & 12 & $30,0 \%$ \\
\hline Prevajanje stavkov iz J 1 (materni jezik) v J 2 (tuji jezik) & 9 & $22,5 \%$ \\
\hline Narek & 6 & $15,0 \%$ \\
\hline Naloge korekcije (popravljanje napak v stavkih ali besedilu) & 6 & $15,0 \%$ \\
\hline Drugo: tvorba vprašanj glede na dani odgovor & $\mathbf{4 0}$ & $\mathbf{2 , 5} \%$ \\
\hline SKUPAJ & & \\
\hline
\end{tabular}

Opazimo lahko (Prikaz 10), da učitelji v svoj pouk vključujejo raznolike naloge, občasno tudi prevajanje stavkov, narek ter naloge za popravljanje napak v stavkih ali besedilih. Iz rezultatov je razvidno, da za utrjevanje jezikovnih/slovničnih oblik največ uporabljajo naloge vstavljanja (77,5\%), naloge nadomeščanja kategorij (62,5\%), tvorjenje stavkov po danem vzorcu $(60,0 \%)$, naloge dopolnjevanja $(57,5 \%)$ in naloge s kratkimi odgovori $(45,0 \%)$. 


\section{ZAKLJUČEK}

Namen prispevka je bil predstaviti vlogo slovnice pri pouku francoščine na slovenskih gimnazijah in srednjih šolah. Najprej smo slovnico opredelili in predstavili teoretične ugotovitve o njenem pomenu $\mathrm{v}$ različnih metodologijah, $\mathrm{v}$ obeh učnih načrtih za francoščino ter orisali njeno spremenjeno vlogo pri eksternih preverjanjih danes.

V osrednjem empiričnem delu smo predstavili raziskovalno vprašanje ter dve eksplicitno izraženi predpostavki. V raziskavi smo sicer uporabili dve metodi pedagoškega raziskovanja, vendar smo se $\mathrm{v}$ tem prispevku osredotočili predvsem na tisti del raziskave, ki je temeljila na anketiranju srednješolskih učiteljev francoščine.

Anketni vprašalnik je bil sestavljen iz štirih vsebinskih sklopov, med katerimi se je zadnji sklop navezoval izključno na poučevanje slovnice. Odgovori anketiranih učiteljev kažejo na to, da ima slovnica pri njihovem poučevanju francoščine sicer pomembno vlogo, vendar njihov pouk poteka tako, da dijaki samostojno odkrivajo jezikovne posebnosti ter urijo slovnične strukture ob komunikacijsko osmišljenih nalogah in dejavnostih.

Večina učiteljev francoščine uporablja za razlago slovnice in za urjenje oblik dodatna gradiva, saj menijo, da $\mathrm{v}$ učbenikih in pripadajočih delovnih zvezkih ni dovolj slovničnih vaj. V poučevanje večinoma vključujejo oba pristopa poučevanja, učenje s sklepanjem in razlago jezikovnih pravil z dodatnimi vajami, kar smo v raziskovalni nalogi poimenovali kombinirana induktivno-deduktivna metoda učenja in poučevanja slovnice.

Rezultati raziskave so pokazali, da se učiteljem slovnica zdi pomembna, vendar v svoj pouk vključujejo različne pristope za razvijanje vseh sporazumevalnih spretnosti. Po njihovem mnenju je razvijanje jezikovne zmožnosti le en element tujejezikovnega pouka, zato se anketirani učitelji pri pouku le redko omejijo izključno na jezikovno zmožnost in pravilnost.

V nasprotju s predhodnimi metodami poudarja komunikacijski pristop (Tagliante 2006: 61) predvsem zaznavne sposobnosti »višjega« reda, kot so opazovanje, razmišljanje in analiza jezikovnih struktur, ki se nahajajo v nekem besedilu. Učenje naj temelji na besedilih oziroma primerih, na katerih dijaki proučujejo in odkrivajo pravila za določeno jezikovno vprašanje.

Sodobni učbeniki za francoščino so komunikacijsko usmerjeni in mnogi med njimi temeljijo na akcijskem pristopu poučevanja. Slovnica je obravnavana v tematskem kontekstu, čeprav določena jezikovna poglavja v sodobnih učbenikih niso predstavljena na celovit način in tako sistematično kot $\mathrm{v}$ preteklosti.

Na osnovi vseh ugotovitev lahko zaključimo s predlogom, da je pri poučevanju francoske slovnice smiselno upoštevati in slediti smernicam, ki jih ponuja učbenik kot temeljno učno gradivo, $v$ smiselno zaokroženih tematskih sklopih in v skladu s smernicami predpisanega učnega načrta, tudi zato, da dijakom zagotovimo sistematično nadgradnjo znanj pri učenju jezika. Poleg tega pa naj se v pouk vključuje poleg dodatnih vaj za 
urjenje jezikovnih oblik in sistematične razlage, tudi naloge in opravila, ki bodo usmerjena v celostno razvijanje vseh prvin sporazumevalne zmožnosti. Smiselno je, da se učitelj pri svojem poučevanju omeji in odloči, katera področja slovnice jezika in pravila bo poučeval in jih vgradi $v$ ustrezen kontekst.

Ob zaključku tega prispevka naj omenimo tudi številne možnosti nadaljnjih raziskav o vprašanjih na področju poučevanja slovnice, ki so se skozi naše raziskovalno delo pojavile. Zanimivo bi bilo na primer ugotoviti, ali induktivno učenje in poučevanje slovnice res prinaša trajnejše in bolj kakovostno znanje jezikovnih struktur in posledično višjo raven znanja jezika, npr. $\mathrm{v}$ primerjavi s prevladujočim deduktivnim pristopom.

\section{LITERATURA \\ Učbeniki}

DOMINIQUE, Philip/ Jacky GIRARDET/Michèle VERDELHAN/Michel VERDELHAN (1988) Le nouveau sans frontières 1. Pariz: CLÉ International.

DUBOIS, Anne-Lise/Fabienne GALLON/Martine LEROLLE (2008) Scénario 1. Pariz: Hachette.

GIRARDET, Jacky/ Jean-Marie GRIDLING (2004) Panorama de la langue française 1. Pariz: CLÉ International.

\section{Drugi viri}

BOYER, Henry/Michèle BUTZBACH/Michèle PENDANX (1990) Nouvelle introduction à la didactique du français langue étrangère. Pariz: CLÉ International.

CAJHEN, Simona in drugi (2011) Sporazumevalna zmožnost pri pouku francoščine, Cajhen S., Kante, Z. (ur.), Posodobitve pouka v gimnazijski praksi. Francoščina. Ljubljana: Zavod RS za šolstvo, 33-38.

CAJHEN, Simona (2013) Poročilo o uvajanju in spremljanju uvajanja posodobljenih učnih načrtov v izobraževalnem programu gimnazija. Predmet: Francoščina kot 2. tuji ali 3. tuji jezik. Ljubljana: Zavod RS za šolstvo. Neobjavljeno delovno gradivo.

CAJHEN, Simona (2013) Vloga slovnice pri poučevanju francoščine kot tujega jezika: magistrska naloga. Univerza $\mathrm{v}$ Ljubljani.

COURTILLON, Janine (2003) Élaborer un cours de FLE. Pariz: Hachette.

CUQ, Jean-P./Isabelle GRUCA (2009) Cours de didactique du français langue étrangère et seconde. Grenoble: Presses universitaires de Grenoble.

Predmetni izpitni katalog za splošno maturo francoščina (2010) Državna predmetna komisija za splošno maturo za francoščino. Ljubljana: Državni izpitni center.

Predmetni izpitni katalog za splošno maturo francoščina (2007) Državna predmetna komisija za splošno maturo za francoščino. Ljubljana: Državni izpitni center. 
GERMAIN, Claude/Hubert SEGUIN (1998) Le point sur la grammaire. Pariz: CLÉ International.

GIRARDET, Jacky (1988) Le nouveau sans frontières 1. Le livre du professeur. Pariz: CLÉ International.

LAH, Meta (2008) Vloga tipa besedila pri razvijanju bralne zmožnosti v tujem jeziku, Skela, J. (ur.), Učenje in poučevanje tujih jezikov na Slovenskem: pregled sodobne teorije in prakse. Ljubljana: Tangram, 305-320.

LAH, Meta/Simona CAJHEN/Zdravka KANTE/Hilda ZALOKAR (2008) Učni načrt. Gimnazija. Francoščina. Ljubljana: Zavod RS za šolstvo.

MIQUEL, Claire (2007) La grammaire bien tempérée V: Le français dans le monde, Revue de la Fédération Internationale des Professeurs de Français. Pariz: CLÉ International, 30-32.

MUSTER, Ana-M. (2008) Slovnica pri pouku nemškega jezika, Skela, J. (ur.), Učenje in poučevanje tujih jezikov na Slovenskem: pregled sodobne teorije in prakse. Ljubljana: Tangram, 383-391.

SKELA, Janez (ur.) (2008) Učenje in poučevanje tujih jezikov na Slovenskem. Pregled sodobne teorije in prakse. Ljubljana: Tangram.

SKELA, Janez (2008) Nazaj v prihodnost: Teorija, praksa in politika poučevanja tujih jezikov v Sloveniji, Ivšek, M. (ur.), Jeziki v izobraževanju (zbornik prispevkov konference). Ljubljana: Zavod RS za šolstvo, 175-196.

SKELA, Janez (1999) Komunikacijska metodologija poučevanja jezikov, Čok, L. (ur.), Učenje in poučevanje tujega jezika. Smernice za učitelje $v$ drugem triletju osnovne šole. Ljubljana. Pedagoška fakulteta, Koper: Znanstveno-raziskovalno središče Republike Slovenije, 176-177.

SKELA, Janez (1999) Vloga slovnice pri učenju/poučevanju tujega jezika, Čok, L. (ur.), Učenje in poučevanje tujega jezika. Smernice za učitelje $v$ drugem triletju osnovne šole, Ljubljana: Pedagoška fakulteta, Koper: Znanstveno-raziskovalno središče Republike Slovenije, 126-133.

Skupni evropski jezikovni okvir: učenje, poučevanje, ocenjevanje (SEJO); ang. CEFR; fr. CECRL: Cadre européen commun de référence pour les langues (2000) Apprendre, enseigner, évaluer. Strasbourg: Divisions des politiques linguistiques.

TAGLIANTE, Christine (2006) La classe de langue. Pariz: CLÉ International.

VUČO, Julijana (2012) O učenju jezikov: Pogled v zgodovino glotodidaktike: od pradavnine do druge svetovne vojne. Ljubljana: Oddelek za romanske jezike in književnosti.

Internetni vir: Učni načrt. Gimnazija. Francoščina (2008) 25. november 2014. http:// portal.mss.edus.si/msswww/programi2010/programi/media/pdf/ucni_nacrti/UN_ FRANCOSCINA_gimn.pdf.

Internetni vir: Francoščina. Predmetni katalog - učni načrt. Gimnazija (1998) 25. november 2014. http://eportal.mss.edus.si/msswww/programi2003/programi/gimnazija/gimnazija/francoscina.htm. 


\section{ABSTRACT}

\section{Attitude of French Teachers towards Teaching Grammar}

The present article is concerned with presenting the importance and role which is given to grammar by Slovenian teachers of the French language in secondary schools. Firstly the concept of grammar is defined and its position throughout history and in both curricula for the French language in Slovenian secondary schools is presented. Furthermore the changing role of grammar in the external exams is presented.

The main part of this article is related to the presentation of the research work and its results, in which we focused mostly on the questionnaire results' presentation.

On the basis of the obtained results we can assume that Slovenian teachers consider grammar as a very important element of teaching, although they make use of different approaches in their teaching in order to develop all components of communicative competence.

They think that linguistic competence is only one element of communicative language competence, therefore they are rarely limited only to linguistic competence and accuracy.

Key words: French lessons, grammar, communication approach, the opinion of teachers, textbooks.

\section{POVZETEK}

\section{Odnos učiteljev francoščine do poučevanja slovnice}

Namen prispevka je predstaviti pomen in vlogo, ki ju učitelji francoščine na slovenskih srednjih šolah in gimnazijah pripisujejo slovnici pri svojem poučevanju. Najprej je opredeljen pojem slovnice in njena vloga skozi zgodovino ter v obeh učnih načrtih za poučevanje francoščine na gimnazijah. Spreminjanje vloge slovnice je predstavljeno skozi perspektivo eksternih preverjanj znanja. $\mathrm{V}$ osrednjem delu prispevka je predstavitev raziskave in rezultatov empiričnega dela raziskovalne naloge, v katerem smo se zaradi obsežnosti omejili zgolj na predstavitev rezultatov anketnih vprašalnikov, ki so relevantni za naše raziskovalno vprašanje.

$\mathrm{Na}$ osnovi rezultatov lahko sklepamo, da se učiteljem francoščine slovnica zdi pomembna, vendar v svoj pouk vključujejo različne pristope za razvijanje vseh sporazumevalnih spretnosti. Menijo, da je razvijanje jezikovne zmožnosti le en element tujejezikovnega pouka, zato se pri poučevanju le redko omejijo izključno na jezikovno zmožnost in pravilnost.

Ključne besede: pouk francoščine, slovnica, komunikacijski pristop, mnenje učiteljev, učbeniki. 